\title{
Physical activity of Czech adolescents: Findings from the HBSC 2010 study
}

\author{
Michal Kalman*, Zdenek Hamrik, Erik Sigmund, Dagmar Sigmundová, Ferdinand Salonna, \\ and Czech National HBSC team
}

Faculty of Physical Culture, Palacký University, Olomouc, Czech Republic

Copyright: (c) 2015 M. Kalman et al. This is an open access article licensed under the Creative Commons Attribution License (http://creativecommons.org/licenses/by/4.0/).

\begin{abstract}
Background: It is well described that moderate-to-vigorous physical activity improves the health status of children and adolescents. Thus, monitoring the levels of physical activity together with the motives to perform is critical for future programs aiming to enhance physical activity in youth and young adults in the Czech Republic and further afield in other Central and Eastern European nations that are in transition. Objective: The aim of this study is to provide basic overview about moderate-to-vigorous physical activity (MVPA), vigorous physical activity (VPA) and motives to physical activity of Czech adolescents on the basis of gender and age group. Methods: Data from the Health Behaviour in School-aged Children (HBSC) study conducted in May-June 2010 in the Czech Republic. The sample consisted of 4,385 Czech pupils ( $48.5 \%$ boys; age $11, n=418$; age 13, $n=1,449$; age 15, $n=1,518$ ). Chi-square test of independence was used to provide basic comparison on basis of gender and age groups. Results: A substantial part of boys and girls are not participating in MVPA and VPA as recommended. MVPA and VPA among girls significantly decreased from age 11 to age 15 . Boys compared to girls reported significantly more moderate-tovigorous and vigorous physical activities in all age groups, except 11 years old adolescents where the level of MVPA among girls and boys did not differ. Girls appear to be more influenced by social motives. Importance of these motives became higher with increasing age. Achievement motivation for physical activity is more important for boys and it also is increasing with age. Conclusions: Better understanding of the motives for physical activity as well as gender and age based differences in physical activity levels can significantly contribute to better planning of national and local intervention promoting active living.
\end{abstract}

Keywords: health, physical activity, HBSC, Czech Republic

\section{Introduction}

Extensive reviews of the literature on children and adolescents indicate that moderate-to-vigorous physical activity (MVPA) improves both short and long term physical and mental health status as general health, bone health, health related quality of life and positive mood states have all been associated with higher levels of daily physical activity (Annesi, 2005; Hallal, Victora, Azevedo, \& Wells, 2006; Iannotti, Janssen et al., 2009; Strong et al., 2005). Negative relationship between physical activity and obesity was also confirmed (Fleming-Moran \& Thiagarajah, 2005). In early and mid-adolescence ${ }^{1}$, physical activity is related to self-image and quality of family and peer relationships

\footnotetext{
* Address for correspondence: Michal Kalman, Department of Recreology, Faculty of Physical Culture, Palacký University, tř. Míru 115, 77111 Olomouc, Czech Republic. E-mail: michal.kalman@upol.cz
}

and negatively related to health complaints and smoking (Iannotti, Kogan, Janssen, \& Boyce, 2009). In addition, there is evidence that increased physical activity improves academic and cognitive performance (Strong et al., 2005; Tomporowski, Davis, Miller, \& Naglieri, 2008).

Numerous studies have documented factors associated with young people's physical activity (Bauman et al., 2012; Ding, Sallis, Kerr, Lee, \& Rosenberg, 2011; Haug, Torsheim, Sallis, \& Samdal, 2010; Sallis, Prochaska, Taylor, Hill, \& Geraci, 1999), suggesting that the key determinants include demographic factors

\footnotetext{
${ }^{1}$ A thorough understanding of adolescence in society depends on information from various perspectives, including psychology, biology, history, sociology, education, and anthropology. Within all of these perspectives, adolescence is viewed as a transitional period between childhood and adulthood, whose cultural purpose is the preparation of children for adult roles (Larson \& Wilson, 2009). In this publication we adhere to definition used by WHO as period between age 10 and 19 .
} 
(younger age, male), psychological factors (such as perceived barriers, competence and enjoyment), social factors (such as encouragement from parents, siblings and peers) and the physical environment (such as the availability of facilities and programmes).

Recommendations for physical activity at population level, for example in terms of intensity and duration, have been widely debated in recent years (Andersen et al., 2006; World Health Organization, 2010). Based on their extensive review of the literature, Strong et al. (2005) developed the recommendation that children participate in at least 60 minutes of moderate to vigorous physical activity daily $^{2}$. These recommendations are consistent with recommendations of governmental and professional organizations (Center for Disease Control and Prevention, 2000; Department of Health, Physical Activity, Health Improvement and Protection of the UK). Andersen et al. (2006) suggest an even longer duration of daily moderate intensity physical activity is necessary to affect the pattern of cardiovascular risk factors. As a secondary recommendation activities improving muscular strength, flexibility and bone health should be undertaken on two or more days a week are suggested (Department of Health, Physical Activity, Health Improvement and Protection of the UK, 2011; WHO, 2010).

Czech adolescents (Lokvencová, Frömel, Chmelík, Groffik, \& Bebčáková, 2011; Lokvencová, Skalik, Frömel, \& Górna-Łukasik, 2011; Sigmundová, El Ansari, Sigmund, \& Frömel, 2011), and their counterparts across Europe (Currie et al., 2012) are living an increasingly sedentary lifestyle. Unfortunately, both secular and age trends indicate a decrease in physical activity in childhood and adolescence and a corresponding increase in childhood obesity (Nader, Bradley, Houts, McRitchie, \& O’Brien, 2008; Nelson \& Gordon-Larsen, 2006; Sigmundová et al., 2011).

The post-communist bloc countries (e.g. the Czech Republic) appear to have a tendency to replicate the "negative" health trends that had been previously witnessed in economically developed Western countries: a decrease in PA and an increase of overweight and obesity (Branca, Nikogosian, \& Lobstein, 2007). Indeed, Central and Eastern European countries could learn from such "negative" Western European and global experiences (Knai, Suhrcke, \& Lobstein, 2007). The adolescent population represents one of the most physically active subpopulations (Le Masurier et al., 2008). Monitoring the levels of PA together with motives to perform is critical for future programs aiming to

\footnotetext{
${ }^{2}$ Moderate intensity was defined as being equivalent to brisk walking, which might leave the participant feeling warm and slightly out of breath.
}

enhance PA in youth and young adults in the Czech Republic and further afield in other Central and Eastern European nations that are in transition.

\begin{abstract}
Aim
The aim of this study is to provide basic overview about moderate-to-vigorous physical activity, vigorous physical activity and motives to physical activity of Czech adolescents on the basis of gender and age group.
\end{abstract}

\section{Methods}

\section{Sample and procedure}

We used data from the Health Behaviour in Schoolaged Children (HBSC) study conducted in May-June 2010 in the Czech Republic. Self-completion questionnaires were administered in school classroom with requirements in terms of sampling, questionnaire items and survey administration being set out in a standardised research protocol. All of the questions used in the HBSC survey must have evidence of reliability and validity when used in multiple countries before they are considered for inclusion (Roberts et al., 2009).

From a list of schools based on information from the Institute for Information on Education, a contributory organization of Ministry of Education, Youth and Sport, 91 schools from all 14 regions of the Czech Republic were randomly chosen to create a representative sample. We contacted 91 schools, and 86 schools took part in our survey, representing a $94.5 \%$ school response rate. According to the protocol of the HBSC study classes from the $5^{\text {th }}$ to $9^{\text {th }}$ grades were selected randomly, one from each grade per school. We obtained data from 5,284 adolescents from the $5^{\text {th }}, 7^{\text {th }}$ and $9^{\text {th }}$ grade of elementary schools in the Czech Republic (response: $87 \%$ ). Non-response due to absence was $13 \%$ (786 pupils). We did not compute how many of them was absent because of illness. For the purpose of the paper were analysed adolescents in the age of 11 years $(n=1,418), 13$ years $(n=1,449)$ and 15 years $(n=1,518)$. The final sample consisted of 4,385 Czech pupils ( $48.5 \%$ boys) (Table 1$)$.

Participation in the study was fully voluntary and anonymous with no explicit incentives provided for participation. Questionnaires were administrated by trained research assistants in the absence of a teacher during regular class time. Parents were informed about the study via the school administration and could opt out if they disagreed with it. 
Table 1

General description of the study sample

\begin{tabular}{lrrrrrrr}
\hline & \multicolumn{2}{c}{ Girls } & & \multicolumn{2}{c}{ Boys } & & Total \\
\cline { 2 - 3 } & $n$ & $\%$ & & $n$ & $\%$ & & $N$ \\
\hline 11 years & 703 & 49.6 & & 715 & 50.4 & & 1,418 \\
13 years & 785 & 54.2 & & 664 & 45.8 & & 1,449 \\
15 years & 771 & 50.8 & & 747 & 49.2 & & 1,518 \\
Total & 2,259 & 51.5 & & 2,126 & 48.5 & & 4,385 \\
\hline
\end{tabular}

\section{Measures}

Demographic data (age, gender) were collected using a single questions used and validated in the Health Behaviour in School-aged Children (HBSC) surveys (Currie et al., 2004; Currie et al., 2008).

Three items measuring physical activity are included in the 2009/2010 HBSC survey, measuring both MVPA and VPA.

\section{Moderate-to-vigorous physical activity (MVPA)}

MVPA was measured with following item:

Physical activity is any activity that increases your heart rate short of breath some time. Physical activity can be performed in sports, school activities, playing with friends, or walking to school. Some examples of physical activity are running, brisk walking, rollerblading, biking, dancing, skateboarding, swimming, soccer, basketball, football, and surfing. For this next question, add up all the time you spent in physical activity each day: "Over the past 7 days, on how many days were you physically active for a total of at least 60 minutes per day?"

\section{Vigorous physical activity (VPA)}

VPA was measured with following two items:

1. Outside school hours: "How often do you usually exercise in your free time so much that you get out of breath or sweat?"

The possible answers were „every day, 4 to 6 times a week, 2 to 3 times a week, once a week, once a month, less than once a month, never".

2. Outside school hours: "How many hours a week do you usually exercise in your free time so much that you get out of breath or sweat?"

The possible answers were „none, about half an hour, about 1 hour, about 2 to 3 hours, about 4 to 6 hours, about 7 hours or more“.

\section{Motives for physical activity}

Motives for physical activity were assessed using a question in HBSC study consisting of 13 items examining why young people undertake leisure time physical activity (Wold \& Kannas, 1993). "Here is a list of reason that some young people give for taking part in physical activity in their free time. For each reason please tick how important it is for you" with possible answers (1) very important; (2) fairly important; (3) not important for the following reasons: (1) to have fun, (2) to be good at sport, (3) to win, (4) to make a new friends, (5) to improve my health, (6) to see my friends, (7) to get in good shape, (8) to look good, (9) I enjoy the feeling of using my body, (10) to please my parents, (11) to be cool, (12) to control my weight, and (13) it is exciting.

\section{Statistical analyses}

To provide basic overview about HBSC data, frequencies and proportions according gender and age groups were calculated for all indicators. Chi-square test of independence was used to provide basic comparison on basis of gender and age groups.

\section{Results}

\section{Moderate-to-vigorous physical activity}

Our findings show that substantial part of boys and girls are not participating in MVPA as recommended (Table 2). Sufficient daily MVPA is varying according age group from $24.8 \%$ to $29.5 \%$ among boys and from $14.3 \%$ to $23.3 \%$ among girls. It means that more than 3 quarters of adolescents did not reported recommended level of daily MVPA. In addition with increasing age the involvement in MVPA among girls became significantly lower $\left(\chi^{2}=38.765, d f=14, p<.001\right)$. Although there are also some age variations in MVPA among boys, the differences between age groups are not statistically significant $\left(\chi^{2}=12.112, d f=14, p=.597\right)$. This leads to gender differences with increasing age. While in 11 years age group the differences between girls and boys in participating MVPA were not significant $\left(\chi^{2}=4.948, d f=7, p=.666\right)$, in older age groups boys attended significantly more MVPA than girls (13 years: $\chi^{2}=40.161, d f=7, p<.001 ; 15$ years: $\chi^{2}=49.179$, $d f=7, p<.001)$.

\section{Vigorous physical activity}

According our findings, portions of adolescents which reported vigorous daily activity from 7 to 4 times per week varied according age group and gender from $23.7 \%$ to $47.4 \%$ (Table 3 ). It means that more than $50 \%$ of adolescents are not involved in VPA for more than half of the week. When comparing the age groups results differ for girls and boys. We can see statistically significant decrease of VPA occurrence among girls from age 11 to age $15\left(\chi^{2}=66.186, d f=12, p<.001\right)$. For example, every day VPA occurrence among girls decreased from $15.9 \%$ at age 11 to $11.4 \%$ at age 13 and to $6.2 \%$ at age 15 . Differences in VPA occurrence 


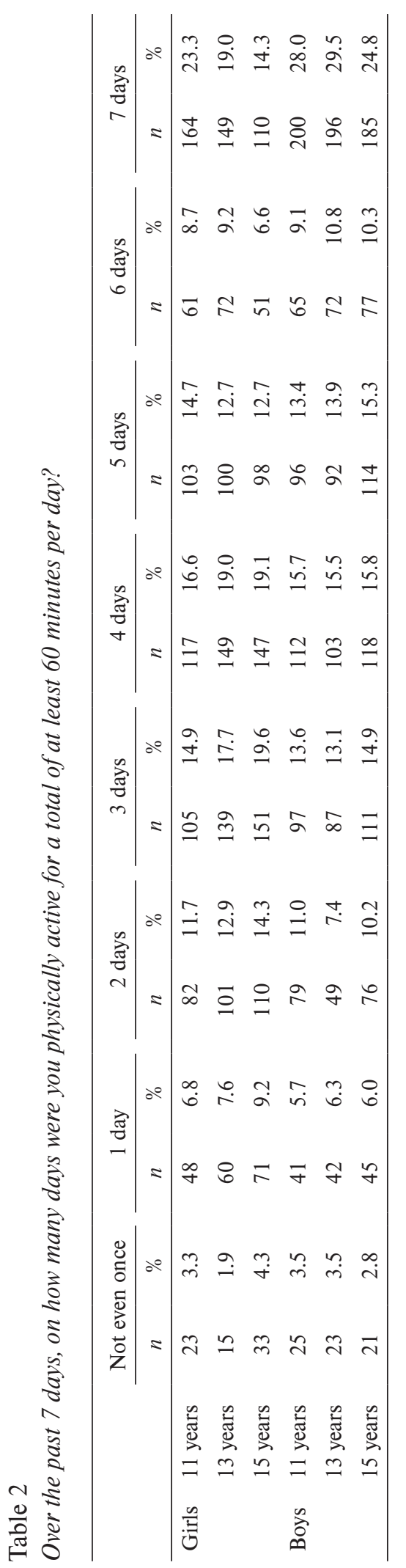

between age groups among boys were not significant $\left(\chi^{2}=16.830, d f=12, p=.156\right)$. VPA was more occurring among boys compared to girls. The difference was significant at age of $11\left(\chi^{2}=32.134, d f=5\right.$, $p<.001)$, age of $13\left(\chi^{2}=50.071, d f=5, p<.001\right)$ and also at age of $15\left(\chi^{2}=68.141, d f=5, p<.001\right)$.

Similarly to MVPA and occurrence of VPA there is pattern of significant decrease of duration of VPA with increasing age $\left(\chi^{2}=19.093, d f=10, p=.039\right)$ (Table 4). For example, at age of 11 more than 35\% of girls have at least 2 hours of VPA per week. This number goes down at age of 13 to more than $33 \%$ to finish at about $28 \%$ at age of 15 . In addition decrease in duration of VPA is significant also among Czech boys $\left(\chi^{2}=31.165, d f=10, p<.001\right)$. It seems that major shift in duration of VPA among boys occurs between age 11 and 13. For example at least 4 hours of VPA was reported by $14.2 \%$ of boys at age $11,9.1 \%$ at age 13 and $9.8 \%$ of boys at age 15 . Similarly to occurrence of VPA among adolescents gender differences between boy and girls were found also for duration of VPA. Boys were involved in longer VPA compared to girls and the difference was significant at age of $11\left(\chi^{2}=17.240, d f=6, p=.008\right)$, age of 13 $\left(\chi^{2}=58.033, d f=6, p<.001\right)$ and also at age of 15 $\left(\chi^{2}=87.814, d f=6, p<.001\right)$.

\section{Motives for physical activity}

Our study also focused on the motives for physical activity among Czech adolescents (Table 5). According reports both form girls and boys, most popular motives among Czech adolescents are "to have fun", "to make a new friends", "to improve my health", "to be cool" or "to see my friends". On the contrary, motive "to win" was reported as not important by the most of girls and boys. When comparing the preferences of particular age groups, motives like "to have fun", "it is exciting", "to look good" or "to see my friends" becoming popular in older age. On the other hand, motives like "make new friends", "to be good at sport", "to improve my health", "to please my parents" or "to control my weight" are less important for older adolescents than for the younger ones. Motives "to be good at sport" and "it is exiting" are much more important for boys compared to girls. On the contrary, motives "to be cool", "to see my friends" and "to make new friends" are more important for girls.

\section{Discussion}

This study provides basic overview about moderate-tovigorous physical activity, vigorous physical activity and motives to physical activity of Czech adolescents 


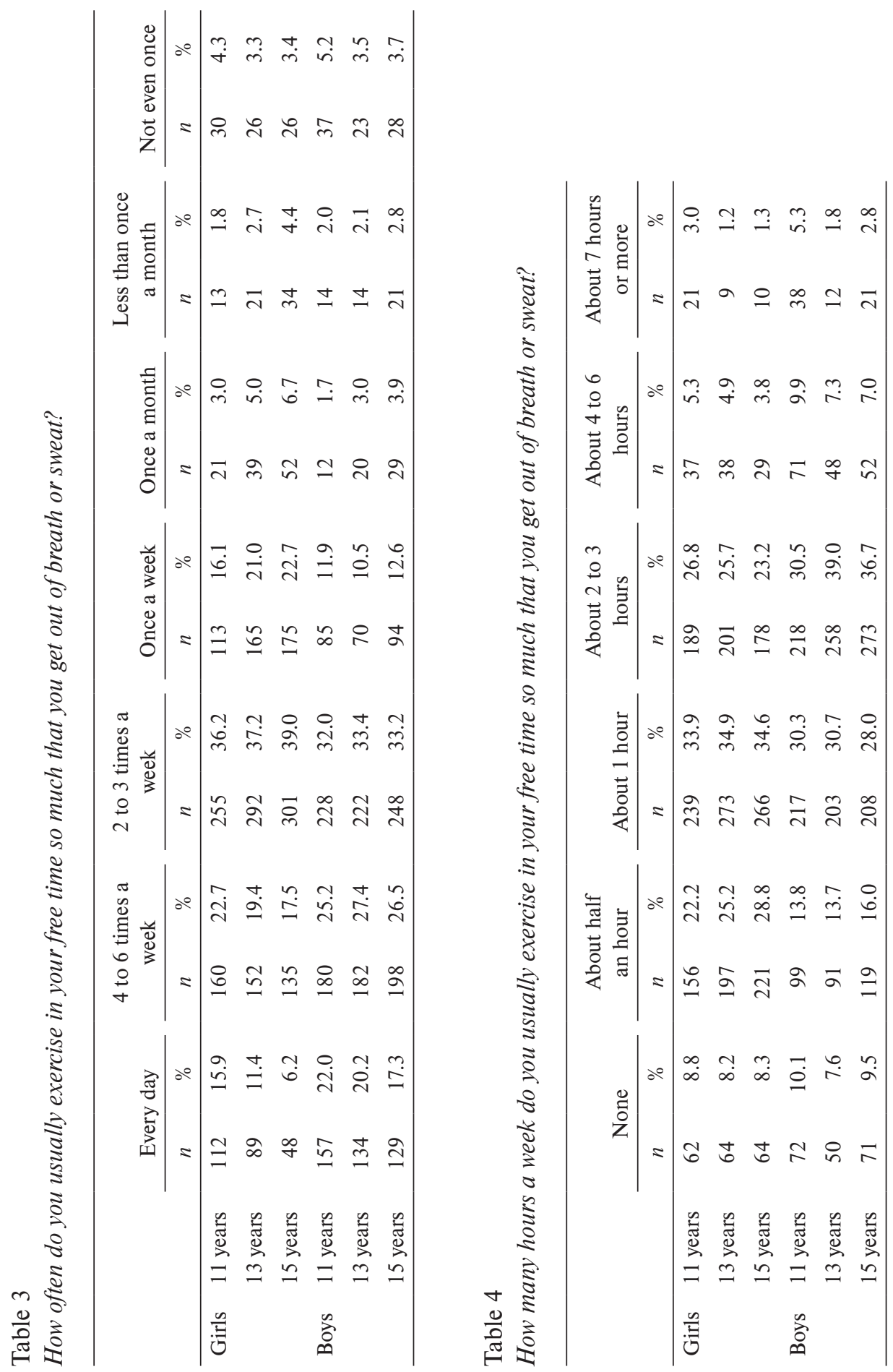

aged from 11 to 15 years based on data collected in 2010.

According our findings substantial part of boys and girls are not participating in MVPA as recommended. This is in line with previous other findings from the Czech Republic (Frömel, Pelclová, Skalik, NovákováLokvencová, \& Mitáš, 2012; Vašíčková, Frömel, Groffik, \& Chmelík, 2013) and Central European region (Bergier, Kapka-Skrzypczak, Bilinski, Paprzycki, \& Wojtyla, 2012; Biddle et al., 2009; Hamar, Biddle,
Soos, Takacs, \& Huszar, 2010; Hoffmann, Bryl, Marcinkowski, Strazynska, \& Pupek-Musialik, 2011; Soos et al., 2012). Although the minimum recommended daily step count is not achieved by a non-negligible part of the Czech adolescent population, they are still considered active walkers (Vašičková, Frömel, Groffik, \& Chmelík, 2013). According to Beets, Bornstein, Beighle, Cardinal, and Morgan (2010), boys and girls from European and Western Pacific region had 
Table 5

Motives for physical activity of Czech adolescents ${ }^{\dagger}$

\begin{tabular}{|c|c|c|c|c|c|c|c|c|c|}
\hline & & \multicolumn{4}{|c|}{ Very important } & \multicolumn{4}{|c|}{ Not important } \\
\hline & & \multicolumn{2}{|c|}{ Girls } & \multicolumn{2}{|c|}{ Boys } & \multicolumn{2}{|c|}{ Girls } & \multicolumn{2}{|c|}{ Boys } \\
\hline & & $n$ & $\%$ & $n$ & $\%$ & $n$ & $\%$ & $n$ & $\%$ \\
\hline \multirow[t]{3}{*}{ To be good at sport } & 11 years & 212 & 30.6 & 331 & 47.0 & 120 & 17.3 & 76 & 10.8 \\
\hline & 13 years & 221 & 28.3 & 302 & 45.8 & 159 & 20.3 & 111 & 16.8 \\
\hline & 15 years & 165 & 21.4 & 297 & 40.0 & 202 & 26.2 & 140 & 18.8 \\
\hline \multirow[t]{3}{*}{ To have fun } & 11 years & 499 & 71.5 & 495 & 69.7 & 19 & 2.7 & 28 & 3.9 \\
\hline & 13 years & 632 & 80.5 & 475 & 71.6 & 10 & 1.3 & 24 & 3.6 \\
\hline & 15 years & 626 & 81.2 & 575 & 77.2 & 8 & 1.0 & 25 & 3.4 \\
\hline \multirow[t]{3}{*}{ To win } & 11 years & 104 & 15.0 & 178 & 25.2 & 392 & 56.5 & 337 & 47.7 \\
\hline & 13 years & 91 & 11.6 & 183 & 27.7 & 412 & 52.6 & 251 & 38.0 \\
\hline & 15 years & 103 & 13.4 & 188 & 25.4 & 413 & 53.6 & 282 & 38.1 \\
\hline \multirow[t]{3}{*}{ To make a new friends } & 11 years & 405 & 58.4 & 388 & 55.3 & 38 & 5.5 & 56 & 8.0 \\
\hline & 13 years & 430 & 54.8 & 333 & 50.6 & 36 & 4.6 & 48 & 7.3 \\
\hline & 15 years & 413 & 53.7 & 336 & 45.3 & 43 & 5.6 & 60 & 8.1 \\
\hline \multirow[t]{3}{*}{ To improve my health } & 11 years & 416 & 59.9 & 494 & 70.1 & 35 & 5.0 & 22 & 3.1 \\
\hline & 13 years & 451 & 57.7 & 433 & 65.8 & 41 & 5.2 & 36 & 5.5 \\
\hline & 15 years & 394 & 51.0 & 426 & 57.3 & 34 & 4.4 & 49 & 6.6 \\
\hline \multirow[t]{3}{*}{ To see my friends } & 11 years & 463 & 66.4 & 422 & 59.9 & 24 & 3.4 & 41 & 5.8 \\
\hline & 13 years & 602 & 76.9 & 422 & 64.0 & 23 & 2.9 & 36 & 5.5 \\
\hline & 15 years & 610 & 79.1 & 524 & 70.5 & 18 & 2.3 & 35 & 4.7 \\
\hline \multirow[t]{3}{*}{ To get in good shape } & 11 years & 276 & 39.7 & 330 & 46.9 & 89 & 12.8 & 77 & 11.0 \\
\hline & 13 years & 355 & 45.5 & 327 & 49.5 & 65 & 8.3 & 66 & 10.0 \\
\hline & 15 years & 373 & 48.3 & 358 & 48.3 & 51 & 6.6 & 76 & 10.3 \\
\hline \multirow[t]{3}{*}{ To look good } & 11 years & 271 & 38.9 & 283 & 40.1 & 114 & 16.4 & 139 & 19.7 \\
\hline & 13 years & 408 & 52.2 & 285 & 43.2 & 75 & 9.6 & 90 & 13.7 \\
\hline & 15 years & 417 & 54.0 & 337 & 45.4 & 58 & 7.5 & 110 & 14.8 \\
\hline \multirow{3}{*}{$\begin{array}{l}\text { I enjoy the feeling of } \\
\text { using my body }\end{array}$} & 11 years & 262 & 37.6 & 327 & 46.2 & 99 & 14.2 & 72 & 10.2 \\
\hline & 13 years & 274 & 35.0 & 275 & 41.7 & 112 & 14.3 & 110 & 16.7 \\
\hline & 15 years & 265 & 34.3 & 264 & 35.6 & 101 & 13.1 & 125 & 16.8 \\
\hline \multirow[t]{3}{*}{ To please my parents } & 11 years & 514 & 73.5 & 499 & 70.8 & 35 & 5.0 & 40 & 5.7 \\
\hline & 13 years & 377 & 48.1 & 310 & 46.9 & 114 & 14.5 & 120 & 18.2 \\
\hline & 15 years & 264 & 34.2 & 233 & 31.4 & 216 & 28.0 & 214 & 28.9 \\
\hline \multirow[t]{3}{*}{ To be cool } & 11 years & 491 & 70.6 & 488 & 69.1 & 18 & 2.6 & 24 & 3.4 \\
\hline & 13 years & 590 & 75.4 & 414 & 62.8 & 14 & 1.8 & 27 & 4.1 \\
\hline & 15 years & 571 & 74.2 & 464 & 62.5 & 13 & 1.7 & 41 & 5.5 \\
\hline \multirow[t]{3}{*}{ To control my weight } & 11 years & 272 & 39.1 & 305 & 43.1 & 102 & 14.7 & 98 & 13.8 \\
\hline & 13 years & 278 & 35.5 & 201 & 30.4 & 144 & 18.4 & 164 & 24.8 \\
\hline & 15 years & 250 & 32.4 & 155 & 20.9 & 133 & 17.3 & 258 & 34.8 \\
\hline \multirow[t]{3}{*}{ It is exciting } & 11 years & 223 & 32.3 & 344 & 48.7 & 169 & 24.5 & 100 & 14.1 \\
\hline & 13 years & 239 & 30.6 & 336 & 51.3 & 205 & 26.2 & 87 & 13.3 \\
\hline & 15 years & 306 & 39.9 & 392 & 52.9 & 109 & 14.2 & 88 & 11.9 \\
\hline
\end{tabular}

${ }^{\dagger}$ Possible answer „Fairly important“ is not presented in the table. 
significantly more steps per day than their counterparts from the U. S. and Canada.

We also found that with increasing age the involvement in MVPA among girls became significantly lower. PA promotion in adolescent girls might be enhanced by offering them their preferred activities, such as dance, aerobics, sport games (Sigmund, Sigmundová, Frömel, \& Vašičková, 2010). With regards to actions to address the gender differences in PA among adolescents Vašíčková, Groffik, Frömel, Chmelík, and Wasowicz (2013) recently published an interesting study. Their aim was to assess whether 4-week monitoring with pedometers can influence differences between the level of PA amongst adolescent girls and boys. As result of the four-week intervention the difference in the overall PA of adolescent girls and boys diminished, together with the difference between school and weekends among girls. The use of pedometers, motivational recording brochures and an Internet programme for maintaining PA for a longer period, supported the continuance for movement of an active and healthy lifestyle among girls significantly more than their use among boys. Another recent study with promising results uncovered the patterns of moderate-to-vigorous physical activity in normal weight and overweight/ obese children before, during, and after school lessons (Sigmund, Sigmundová, Šnoblová, \& Gecková, 2014). They found that adding one physical education lessons or an equivalent amount of MVPA to the daily school routine appears to be a promising strategy to effectively increase daily MVPA, particularly among overweight/ obese girls.

On the other hand, boys usually prefer sports games (Sigmund, Frömel, Klimtová, \& Tomik, 2000). However, despite the popularity of sports games, in boys, the current study found a negative secular change in time spent playing games. Achieving sufficient PA in adolescence appeared to be most beneficial in enhancing adult PA e.g. adolescents' (boys) participation in ball games increased their participation in ball games in adulthood (Tammelin, Nayha, Hills, \& Jarvelin, 2003).

Particular age groups differed in some of the motives for PA. For example, motives like "to have fun", "it is exciting", "to look good" or "to see my friends" becoming popular in older age. On the other hand, motives like "to be good at sport", "to improve my health" or "to please my parents" are less important for older adolescents than for the younger ones. In addition, motives "to be cool", "to see my friends" and "to make new friends" are more important for girls. As the children grow the peer pressure increases and social motives strengthen. Especially girls appear to be more influenced by social motives. Camacho-Miñano,
LaVoi, and Barr-Anderson (2011) recommend making physical activity enjoyable for girls by increasing the choices and offering a wide range of non-competitive and innovative activities. Social motivation could be the way to reduce difference in level of physical activity between female and male adolescents (Litt, Iannotti, \& Wang, 2011).

It was expected and also in line with other previous studies (Iannotti et al., 2013; Litt et al., 2011; Wold \& Kannas, 1993) that achievement is more important for boys and also is increasing with age. It is important to note that the study was conducted on the sample from a post-communist European country where adolescents report less health and social motives for PA and more motivation oriented to achievements than adolescent in Western Europe or North America (Iannotti et al., 2013).

\section{Strengths and limitations}

It is important to consider certain limitations and assets of this study. An important strength is that we collected relevant data from a nationally-representative sample of adolescents from two countries from the age groups relevant for establishing health-related behaviour. A limitation of our study is that the results are based on self-reported data. However, self-reporting has been shown to offer satisfying reliability in terms of health-related behaviour. Moreover, personal motivations are usually based on self-report and the items used to assess physical activity have been shown to have reasonable reliability and validity (Prochaska, Sallis, \& Rupp, 2001). The questionnaires were filled out anonymously and with assurances of confidentiality. The main limitation, however, is the cross-sectional design of our study, which makes it impossible to formulate conclusive statements about causality in our findings. They therefore need to be confirmed in studies with a longitudinal design.

\section{Conclusion}

A substantial part of boys and girls are not participating in MVPA as recommended. In addition with increasing age the involvement in MVPA among girls became significantly lower. Girls differ in motivation for physical activity from boys. Better understanding of the motives for physical activity as well as gender- and age-based differences in physical activity levels can significantly contribute to better planning of national and local intervention promoting active living. 


\section{Acknowledgment}

This paper was supported by the ECOP project "Strengthening the scientific potential of research teams in promoting physical activity at Palacký University" (reg. no. CZ.1.07/2.3.00/20.0171), by the project "Support for creating excellent research teams and intersectoral mobility at Palacký University in Olomouc" (reg. no. CZ.1.07/2.3.00/30.0004), by the Czech Ministry of Education, Youth and Sports (MEYS) under contracts no. LG 14042 and no. LG 14043, and by the IGA UP research project "Leisure time in school-aged children - HBSC study" (reg. no. FTK_2013_020).

\section{References}

Andersen, L. B., Harro, M., Sardinha, L. B., Froberg, K., Ekelund, U., Brage, S., \& Anderssen, S. A. (2006). Physical activity and clustered cardiovascular risk in children: A cross-sectional study (The European youth heart study). Lancet, 368, 299-304. doi:10.1016/ S0140-6736(06)69075-2

Annesi, J. J. (2005). Correlations of depression and total mood disturbance with physical activity and self-concept in preadolescents enrolled in an after-school exercise program. Psychological Reports, 96, 891-898. doi: 10.2466/ pr0.96.3c.891-898

Bauman, A. E., Reis, R. S., Sallis, J. F., Wells, J. C., Loos, R. J. F., Martin, B. W., \& Lancet Physical Activity Series Working Group. (2012). Correlates of physical activity: why are some people physically active and others not? Lancet, 380, 258-271. doi:10.1016/S0140-6736(12)60735-1

Beets, M. W., Bornstein, D., Beighle, A., Cardinal, B. J., \& Morgan, C. F. (2010). Pedometer-measured physical activity patterns of youth: A 13 country review. American Journal of Preventive Medicine, 38, 208-216. doi:10.1016/j. amepre.2009.09.045

Bergier, J., Kapka-Skrzypczak, L., Bilinski, P., Paprzycki, P., \& Wojtyla, A. (2012). Physical activity of Polish adolescents and young adults according to IPAQ: A population based study. Annals of Agricultural and Environmental Medicine, 19, 109-115.

Biddle, S. J. H., Soos, I., Hamar, P., Sandor, I., Simonek, J., \& Karsai, I. (2009). Physical activity and sedentary behaviours in youth: Data from three Central-Eastern European countries. European Journal of Sport Science, 9, 295-301. doi:10.1080/17461390902829234

Branca, F., Nikogosian, H., \& Lobstein, T. (Eds.). (2007). The challenge of obesity in the WHO European region and the strategies for response: Summary. Copenhagen: WHO Regional Office for Europe.

Camacho-Miñano, M. J., LaVoi, N. M., \& Barr-Anderson, D. J. (2011). Interventions to promote physical activity among young and adolescent girls: A systematic review. Health Education Research, 26, 1025-1049. doi:10.1093/ her/cyr040

Center for Disease Control and Prevention. (2000). Promoting better health for young people through physical activity and sports: A report to the President. Washington, DC: U. S. Government Printing Office.

Currie, C., Gabhainn, S. N., Godeau, E., Roberts, C., Smith, R., Currie, D., ... Barnekow, V. (Eds.). (2008). Inequalities in young people's health: HBSC international report from the 2005/2006 survey. Copenhagen: WHO Regional Office for Europe.

Currie, C., Roberts, C., Morgan, A., Smith, R., Settertobulte, W., Samdal, O., ... Barnekow Rasmussen, V. (2004). Young people's health in context: International report from the HBSC 2001/2002 survey. Copenhagen: WHO Regional Office for Europe.

Currie, C., Zanotti, C., Morgan, A., Currie, D., V. de Looze, M., Roberts, C., ... Barnekow, V. (Eds.). (2012). Social determinants of health and well-being among young people. Health Behaviour in School-aged Children (HBSC) study: International report from the 2009/2010 survey. Copenhagen: WHO Regional Office for Europe.

Department of Health, Physical Activity, Health Improvement and Protection of the UK. (2011). Start active, stay active: A report on physical activity for health from the four home countries' Chief Medical Officers. Retrieved from https://www.gov.uk/government/publications/start-activestay-active-a-report-on-physical-activity-from-the-fourhome-countries-chief-medical-officers

Ding, D., Sallis, J. F., Kerr, J., Lee, S., \& Rosenberg, D. E. (2011). Neighborhood environment and physical activity among youth: A review. American Journal of Preventive Medicine, 41, 442-455. doi:10.1016/j.amepre.2011.06.036

Fleming-Moran, M., \& Thiagarajah, K. (2005). Behavioral interventions and the role of television in the growing epidemic of adolescent obesity - data from the 2001 youth risk behavioral survey. Methods of Information in Medicine, 44, 303-309. doi:10.1267/METH05020303

Frömel, K., Pelclová, J., Skalik, K., Nováková-Lokvencová, P., \& Mitáš, J. (2012). The association between participation in organised physical activity and level of physical activity and inactivity in adolescent girls. Acta Universitatis Palackianae Olomucensis. Gymnica, 42(1), 7-16.

Hallal, P. C., Victora, C. G., Azevedo, M. R., \& Wells, J. C. (2006). Adolescent physical activity and health: A systematic review. Sports Medicine, 36, 1019-1030.

Hamar, P., Biddle, S., Soos, I., Takacs, B., \& Huszar, A. (2010). The prevalence of sedentary behaviours and physical activity in Hungarian youth. European Journal of Public Health, 20, 85-90. doi:10.1093/eurpub/ckp100

Haug, E., Torsheim, T., Sallis, J. F., \& Samdal, O. (2010). The characteristics of the outdoor school environment associated with physical activity. Health Education Research, 25, 248-256. doi:10.1093/her/cyn050

Hoffmann, K., Bryl, W., Marcinkowski, J. T., Strazynska, A., \& Pupek-Musialik, D. (2011). Estimation of physical activity and prevalence of excessive body mass in rural and urban Polish adolescents. Annals of Agricultural and Environmental Medicine, 18, 398-403.

Iannotti, R. J., Chen, R., Kololo, H., Petronyte, G., Haug, E., \& Roberts, C. (2013). Motivations for adolescent participation in leisure-time physical activity: International differences. Journal of Physical Activity and Health, 10, 106-112.

Iannotti, R. J., Janssen, I., Haug, E., Kololo, H., Annaheim, B., Borraccino, A., \& HBSC Physical Activity Focus Group. (2009). Interrelationships of adolescent physical activity, screen-based sedentary behaviour, and social 
and psychological health. International Journal of Public Health, 54(Suppl. 2), 191-198.

Iannotti, R. J., Kogan, M. D., Janssen, I., \& Boyce, W. F. (2009). Patterns of adolescent physical activity, screenbased media use, and positive and negative health indicators in the U. S. and Canada. The Journal of Adolescent Health, 44, 493-499. doi:10.1016/j.jadohealth.2008.10.142

Knai, C., Suhrcke, M., \& Lobstein, T. (2007). Obesity in Eastern Europe: An overview of its health and economic implications. Economics and Human Biology, 5, 392-408. doi:10.1016/j.ehb.2007.08.002

Larson, R., \& Wilson, S. (2009). The scientific study of adolescent development. Historical and contemporary perspectives. In R. Lerner \& L. Steinberg (Eds.), Handbook of adolescent psychology (3rd ed., pp. 3-14). New York, NY: Wiley.

Le Masurier, G. C., Bauman, A. E., Corbin, C. B., Konopack, J. F., Umstattd, R. M., \& Van Emmerik, R. E. (2008). Assessing walking behaviors of selected subpopulations. Medicine and Science in Sports and Exercise, 40(Suppl. 7), S594-S602. doi:10.1249/MSS.0b013e31817c68b1

Litt, D. M., Iannotti, R. J., \& Wang, J. (2011). Motivations for adolescent physical activity. Journal of Physical Activity and Health, 8, 220-226.

Lokvencová, P. N., Frömel, K., Chmelík, F., Groffik, D., \& Bebčáková, V. (2011). School and weekend physical activity of 15-16 year old Czech, Slovak and Polish adolescents. Acta Universitatis Palackianae Olomucensis. Gymnica, 4l(3), 39-45.

Lokvencová, P. N., Skalik, K., Frömel, K., \& Górna-Łukasik, K. (2011). An analysis of school physical activity in adolescent girls. Acta Universitatis Palackianae Olomucensis. Gymnica, 41(2), 65-70.

Nader, P. R., Bradley, R. H., Houts, R. M., McRitchie, S. L., \& O’Brien, M. (2008). Moderate-to-vigorous physical activity from ages 9 to 15 years. JAMA: The Journal of the American Medical Association, 300, 295-305. doi:10.1001/ jama.300.3.295

Nelson, M. C., \& Gordon-Larsen, P. (2006). Physical activity and sedentary behavior patterns are associated with selected adolescent health risk behaviors. Pediatrics, 117, 1281-1290. doi:10.1542/peds.2005-1692

Prochaska, J. J., Sallis, J. F., \& Rupp, J. (2001). Screening measure for assessing dietary fat intake among adolescents. Preventive Medicine, 33, 699-706. doi:10.1006/ pmed.2001.0951

Roberts, C., Freeman, J., Samdal, O., Schnohr, C. W., de Looze, M. E., Nic Gabhainn, S., ... International HBSC Study Group. (2009). The Health Behaviour in Schoolaged Children (HBSC) study: Methodological developments and current tensions. International Journal of Public Health, 54(Suppl. 2), 140-150. doi:10.1007/ s00038-009-5405-9

Sallis, J. F., Prochaska, J. J., Taylor, W. C., Hill, J. O., \& Geraci, J. C. (1999). Correlates of physical activity in a national sample of girls and boys in grades 4 through 12 . Health Psychology, 18, 410-415. doi:10.1037/0278-6133.18.4.410

Sigmund, E., Frömel, K., Klimtová, H., \& Tomik, R. (2000). Structure and level of physical activity in children aged 11-12 according to the body weight. Acta Universitatis Palackianea Olomucensis. Gymnica, 30(1), 25-31.

Sigmund, E., Sigmundová, D., Frömel, K., \& Vašíčková, J. (2010). Preferred contents in Physical Education lessons positively evaluated means for the achievement of a higher intensity of physical activity by girls. Acta Universitatis Palackianae Olomucensis. Gymnica, 40(2), 7-16.

Sigmund, E., Sigmundová, D., Šnoblová, R., \& Gecková, A. M. (2014). ActiTrainer-determined segmented moderateto-vigorous physical activity patterns among normal weight and overweight to obese Czech schoolchildren. European Journal of Pediatrics, 173, 321-329. doi:10.1007/ s00431-013-2158-5

Sigmundová, D., El Ansari, W., Sigmund, E., \& Frömel, K. (2011). Secular trends: A ten year comparison of the amount and type of physical activity and inactivity of random samples of adolescents in the Czech Republic. BMC Public Health, 11, 731. doi:10.1186/1471-2458-11-731

Soos, I., Biddle, S., Boros-Balint, I., Sandor, I., Szabo, P., Hamár, P., \& Simonek, J. (2012). Prevalence of sedentary behaviour in young people in Romania and Slovakia. European Physical Education Review, 18, 19-46. doi:10.1177/1356336X11430659

Strong, W. B., Malina, R. M., Blimkie, C. J., Daniels, S. R., Dishman, R. K., Gutin, B., ... Trudeau, F. (2005). Evidence based physical activity for school-age youth. The Journal of Pediatrics, 146, 732-737. doi:10.1016/j.jpeds.2005.01.055

Tammelin, T., Nayha, S., Hills, A. P., \& Jarvelin, M. R. (2003). Adolescent participation in sports and adult physical activity. American Journal of Preventive Medicine, 24, 22-28.

Tomporowski, P. D., Davis, C. L., Miller, P. H., \& Naglieri, J. A. (2008). Exercise and children's intelligence, cognition, and academic achievement. Educational Psychology Review, 20, 111-131. doi:10.1007/s 10648-007-9057-0

Vašičková, J., Frömel, K., Groffik, D., \& Chmelík, F. (2013). Decrease in weekend number of steps in adolescents. Acta Universitatis Palackianae Olomucensis. Gymnica, 43(1), 49-55.

Vašíčková, J., Groffik, D., Frömel, K., Chmelík, F., \& Wasowicz, W. (2013). Determining gender differences in adolescent physical activity levels using IPAQ long form and pedometers. Annals of Agricultural and Environmental Medicine, 20, 749-755.

World Health Organization. (2010). Global recommendations on physical activity for health. Retrieved from http://www.who.int/dietphysicalactivity/ publications/9789241599979/en/

Wold, B., \& Kannas, L. (1993). Sport motivation among young adolescents in Finland, Norway and Sweden. Scandinavian Journal of Medicine and Science in Sports, 3, 283-291. 